\title{
RECENT ADVANCEMENT IN TALL EARTHQUAKE RESISTANT STRUCTURES
}

Hanns U. Baumann, S.E. Baumann Research and Development Corporation San Clemente, California

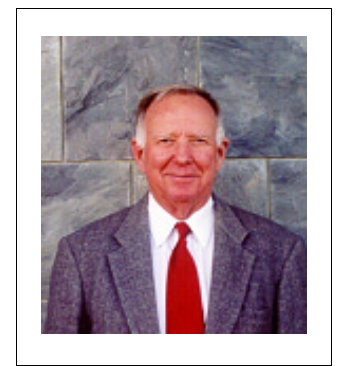

Hanns U. Baumann received his civil engineering degree from the Univ. of California at Berkeley, and his masters in structural engineering from the University of Southern California. To learn more about Hanns, visit www.brdcorp.com

\section{SUMMARY}

After extensive development and testing, the world's tallest precast concrete building has been constructed using proprietary Welded Reinforcement Grid (WRG) reinforcement that saves cost, time and labor. Also recently completed with construction time reduced by $40 \%+$ is a 42 -story building. A 47 -story building is planned at a rate of a floor every three days, using tall WRG reinforcement cages that connect easily on site to rapidly construct elevator shear cores, that resist gravity, earthquake and blast forces very efficiently. Fatigue testing is underway in preparation for its possible use in segmental bridges, where the dimensional accuracy of $\pm 3 \mathrm{~mm}$ allows automation of the reinforcing cage assembly.

Keywords: Welded Reinforcement Grids, WRG, earthquake resistant, reinforcement steel, precast concrete

\section{INTRODUCTION}

Design engineers, research engineers and construction engineers have been working closely together to develop a better way to build concrete structures that are earthquake and blast resistant, using a new proprietary reinforcement technology they have developed and tested since 1987. [1]

\section{NEW WELDED REINFORCEMENT GRID (WRG) TECHNOLOGY}

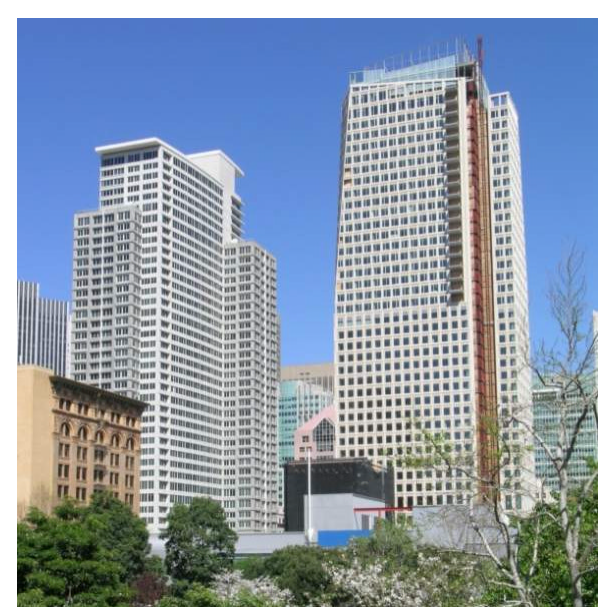

Figure 1 - 39-story Paramount Bldg., left and 42-story St. Regis Building in San Francisco
A result of the joint effort is a remarkable advancement in construction technology. At first glance, what might appear to be trivial, is, in reality, a convergence of new technology resulting in the rapid construction of the world's tallest precast concrete building in a zone of highest seismic risk, in San Francisco, CA [Fig. 1]. It also resulted in a 42-story cast-inplace concrete building structure, using these new technologies, accelerating its construction schedule from a completed floor every seven days to a floor completed every four days. On this same 42-story structure, the St. Regis Museum Tower in San Francisco [Fig.1], one WRG ladder replaced thirty-two (32) pieces of conventional transverse reinforcement. Because the 32 pieces occurred at $10 \mathrm{~cm}$ centers, there was a dramatic reduction not only in the number of pieces of steel used in each cage, but in the time and labor 
needed to assemble the cages with about 100,000 fewer pieces to place.

Based on this experience with the new technology, a 49-story building, soon to be built in San Francisco, will be constructed at a rate of a floor completed every three days.

One of the most significant aspects of these noteworthy advances in construction technology is a deceptively insignificant appearing new reinforcement product. It is a Welded Reinforcement Grid

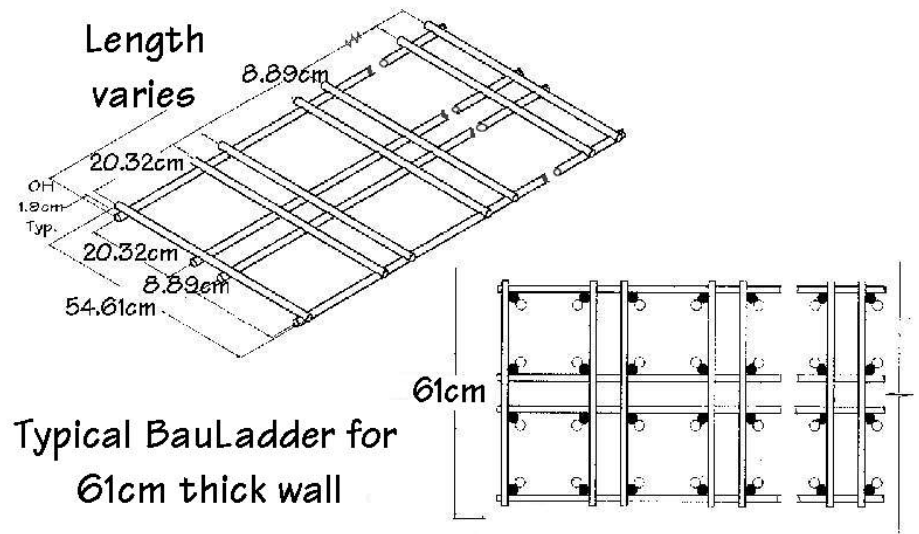

Figure 2 - Typical BauLadder for $61 \mathrm{~cm}$ thick wall
(WRG) that serves mainly as transverse reinforcement in columns, beams, frames and wall boundary elements [Fig. 2]. The exact dimensional tolerances of WRG, just $\pm 3 \mathrm{~mm}$, makes it very useful for reinforcement of precast concrete members in its present form, and soon will allow rapid automated fabrication of rebar cages for both precast and cast-in-place applications.

On the recently completed, $100,000 \mathrm{~m}^{2}, 18$ story Ocean Villa Apartment project in Long Beach, CA, cage assembly labor teams were reduced by half, and the time spent by the reduced team was also cut in

half. Even without automation, this translates to a cage assembly labor reduction of more than $75 \%$, when WRG was used in place of conventional hoops and cross-ties.

\section{RAPID CONSTRUCTION OF TALL EARTHQUAKE AND BLAST RESISTANT BUILDINGS IN CALIFORNIA}

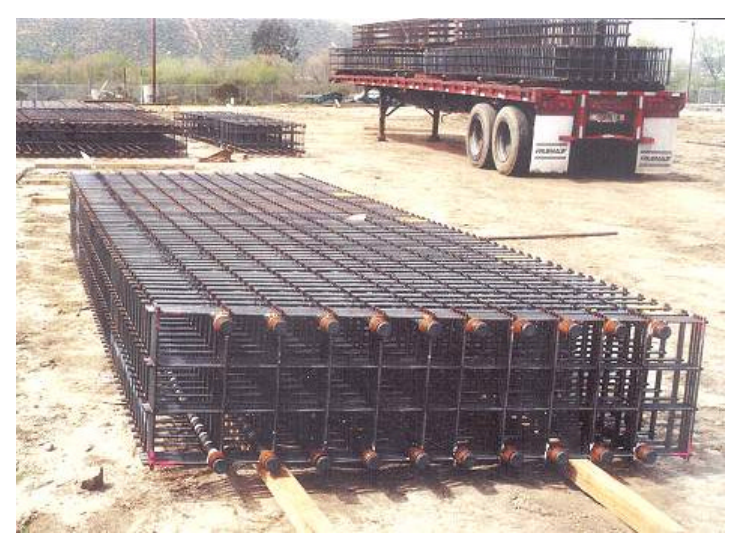

Several new advances in design and construction technology have combined to make it possible to rapidly construct tall, high-quality, earthquake and blast resistant buildings this way. The fabrication of failsafe WRG is now possible with the recent development of consistently high quality welds, made by computer controlled automated welding machines. Tied closely to this state-of-the-art manufacturing process is a quality assurance program, overseen by a third-party certified by the International Conference of Building Officials (ICBO).

Figure 3 - Cage made with BauLadders, which, as shown, also ship very compactly

\section{EARTHQUAKE AND BLAST RESISTANCE DESIGN}

In addition, design and construction engineers, with their research engineer teammates, have developed a very rapid method for constructing cost-effective tall earthquake and blast resistant buildings by using the elevator core as the major element resisting lateral earthquake and blast forces. The new WRG technology permits the rapid installation of tall reinforcement cages for 
these elevator cores. A proprietary method of connecting the common vertical edges of the tall cages also accelerates the cage installation and core construction (Fig. 4).

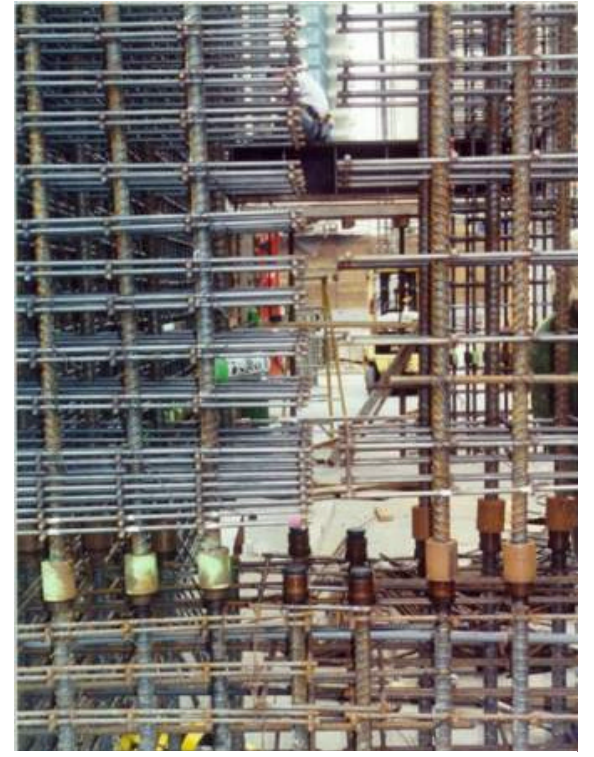

Figure 4 - Proprietary connection method allows rapid erection of elevator core cages
The closely spaced horizontal WRG ladders, having numerous welded joints, give the tall cages a great resistance to deformation, so forms can be rapidly installed.

\section{SELF-CLIMBING FORMS}

To relieve the on-site crane from having to take time to move the core wall forms, newly developed, self-climbing forms have been found quite useful at accelerating construction.

\section{SELF-CONSOLIDATING CONCRETE}

Another converging new technology is self-consolidating concrete that allows much faster placement of concrete, and allows the use of concrete pumps which further frees the project tower cranes and also eliminates the need of a vibrator.

\section{HOOK-FREE WRG}

Faster concrete placement is made possible with the use of WRG because there are no hooks interfering with the passage of the concrete and rapid bottom-up placement is possible.

\section{IMPROVEMENT OF DUCTILITY}

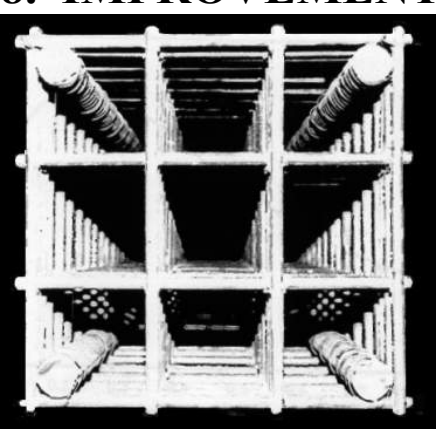

Figure 5 - Test column from research by Prof. Murat Saatcioglu

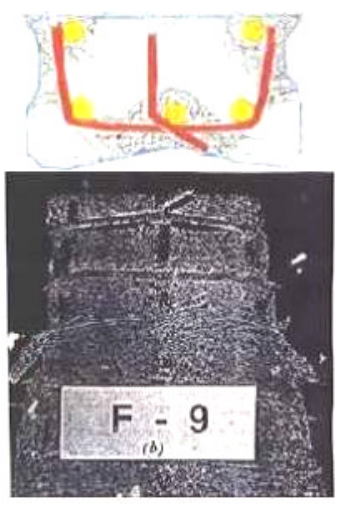

Tests by Prof. Murat Saatcioglu at the Ottawa Carleton Earthquake Engineering Research Centre [2] [Fig. 5] have shown that concrete specimens reinforced with WRG have shown superior ductility, which he attributes to "inter-cell confinement" of the individual cells. He also showed improved ductility with specimens cast with high performance concrete (HPC). Testing of Light Weight HPC specimens reinforced with WRG for use in long span bridge construction is underway.

\section{RELIABILITY OF WRG COMPARED TO CROSS-TIES}

It has been shown by Prof. Shamin Sheik at the University of Toronto [3] [Fig. 6] that conventional cross-ties with $90^{\circ}$ hooks embedded in concrete cover fail prematurely when the cover is lost due to spalling. On the other hand, Prof. V.V. Bertero, in tests performed at the University of California, Berkeley, has shown that WRG does not suffer from this issue. The WRG reinforced specimen cast by Prof. Bertero without cover performed the same as those cast with cover, and both WRG reinforced specimens had performance superior to conventional confinement reinforcement.

Figure 6 - Failure of conventional hooks in Prof. Sheik's research 


\section{TALL BRIDGE PIERS WITH WRG REINFORCEMENT}

The new construction technology for rapid construction of earthquake and blast resistant building using the elevator core walls as the main lateral load resistor is now being applied to the design of frames and hollow bridge piers. As an example, on a bridge to be constructed in the state of Nevada, just four (4) WRG ladders will replace sixty (60) pieces of conventional confinement reinforcement every $10 \mathrm{~cm}$ of the 19.2 meter height of the hollow piers up to the underside of the bridge. In other words, fewer than $800 \mathrm{WRG}$ ladders will replace more than 11,000 pieces of conventional confinement reinforcement.

\section{CONCLUSIONS}

Researchers have shown that there are problems with conventional reinforcement, and that WRG performs in a superior manner to conventional reinforcement. Conventional reinforcement, when used in the field, has been shown to be labor intensive, and, when used in ductile and blast resistant structures, to cause congestion that leads to problems in constructibility. Through use in the field, WRG has been shown to accelerate construction times, reduce labor costs and the number of pieces of reinforcement to be handled.

Working together, research engineers, design engineers and construction engineers have, using WRG and other new technology such as self-climbing forms and self-consolidating concrete, developed a very rapid method for constructing cost-effective tall earthquake and blast resistant buildings by using the elevator core as the major element resisting lateral earthquake and blast forces.

The new WRG technology permits the rapid installation of tall reinforcement cages for these elevator cores. A proprietary method of connecting the common vertical edges of the tall cages also accelerates the cage installation and core construction.

The new construction technology for rapid construction of earthquake and blast resistant buildings, using the elevator core walls as the main lateral load resistor, is now being applied to the design of frames and hollow bridge piers. This system promises to also improve constructibility and provide superior structures for the bridge industry, as well, at a reduced cost.

\section{ACKNOWLEDGEMENTS}

The author would like to apologize in advance to any one who has contributed to the development of the WRG system but is not acknowledged in the following partial list of acknowledgements. It has been a fifteen year effort, and the contributions are too numerous to include here, but the author did wish in this paper to specifically acknowledge the efforts of the following researchers: Prof. Eduardo Miranda, Prof. Vitelmo V. Bertero, Prof. Murat Saatcioglu, Prof. Robin Shepherd, Prof. Shamin Sheik, Prof. M.J. Nigel Priestley, Prof. Frieder Seible, Dr. S.K. Ghosh, Prof. John Stanton, Geraldine Cheok, William Stone. He would also like to acknowledge the engineering contributions of Robert Englekirk, Brett Kaufmann and Tony Ghodsi of Englekirk and Associates, Ron Klemencic of Magnusson Klemencic, Troy Bankston of CalTrans, Susan Nakaki of the Nakaki Bashaw Group, Neville Mathias of SOM, Eric Lehmkuhl of KPFF and Chris Thompson. In the construction industry, the author would like to acknowledge the contributions of Dave Seagren, Joe Sanders, Tom Verti and Dean Stephan at Charles Pankow Builders, Ltd., Al Fink at Midstate Precast, LLC, Boyd Kelley at Regional Steel RPS, Walter Mawby, Larry Fitch and Dathan Heeran of Highrise Concrete Systems, Inc. Thank you to all for your contributions. 


\section{REFERENCES}

[1] MIRANDA, E., THOMPSON, C.L., BERTERO V.V., 1990 "Cyclic Behavior Of Shearwall Boundary Elements Incorporating Prefabricated Welded Wire Hoops" - A Report To Sponsor Baumann Engineering" EERC College of Engineering, UCB

BAUMANN, H., 1991 “A New Confinement Device For Tall Ductile Shearwall Buildings" Council on Tall Buildings and Urban Habitat, Lehigh University, Proceedings of the Second Conference on Tall Buildings in Seismic Regions, pp. 61-70

BAUMANN, H., 1993 "Performance Of Prefabricated High Strength Welded Wire Grids In Ductile Concrete Shear Wall Boundary Elements" - John Wiley and Sons, Ltd., London, International Journal of the Structural Design of Tall Buildings, Vol. 2, pp. 33-52

BAUMANN, H., 1993 "Welded Wire Confinement Grids" - American Society of Civil Engineers, New York, Structural Engineering in Natural Hazards Mitigation, Vol. 1, pp. 295300

BAUMANN, H., 1997 "Report Of Recent Advances In The Development Of Welded Reinforcement Grid Products And Processes" - The Printing House, Stoughton, Wisconsin, Proceedings of the Fourth Conference on Tall Buildings in Seismic Regions, pp. 277-290

[2] SAATCIOGLU, M. AND GRIRA, M., 1996, "Concrete Columns Confined with Welded Reinforcement Grids," Ottawa Carleton Earthquake Engineering Research center - Report OCEERC 96-05, September

[3] SHEIKH, M. AND TOKLUCU, M., 1993, "Reinforced Concrete Confined by Cylinder Spirals and Hoops", ACI Structural Journal, September-October 